\title{
NEW SPACES IN THE PUBLIC ARENA: LEARNINGS FROM GIPUZKOA
}

\section{Felix Arrieta}

Lecturer and researcher in Social Policy, Department of Social Work and Sociology, University of Deusto. Address: Universidad de Deusto, Camino Mundaiz, 50, 20012 Donostia-San Sebastián, Guipúzcoa, Spain. E-mail: felix.arrieta@deusto.es

\section{Ainhoa Izaguirre}

Lecturer and researcher in Social Work, Department of Social Work and Sociology, University of Deusto. Address: Universidad de Deusto, Camino Mundaiz, 50, 20012 Donostia-San Sebastián, Guipúzcoa, Spain.

E-mail: ainhoa.izagirre@deusto.es

\section{Martín Zuñiga}

Lecturer and researcher in Social Work, Department of Social Work and Sociology, University of Deusto. Address: Universidad de Deusto, Camino Mundaiz, 50, 20012 Donostia-San Sebastián, Guipúzcoa, Spain.

E-mail: martin.zuni@deusto.es

\section{Abstract \\ The difficulties that European Welfare States are experiencing in order to respond to emerging social needs are making a re-configuration of the welfare system inevitable. In this sense, spheres such as the third sector are gaining special attention due to their role in the provision of welfare. This paper qualitatively addresses the interaction between public administration and the third sector using the example of welfare provision in the Province of Gipuzkoa. Specifically, our research focuses on the existing instruments for this interaction and the existing spaces for representation and interaction between both. \\ By means of a participatory approach based on qualitative techniques, professionals from the public administration and the third sector were given voice. Semi-structured interviews were carried out with nine participants considered by the research team as ref- erences in the field of the third sector. To complement and advance in the understanding of the information obtained, three discussion groups were also set up: two were formed by participants who are in charge of third sector organizations; and the third was made up of technicians from the Provincial Council of Gipuzkoa. \\ Altogether, the results obtained illustrate much confusion between both actors con- cerning how their relationships should be built, as traditional ways seem insufficient. Although the creation of the civil dialogue table seems like an alternative, it presents sev- eral difficulties in terms of ensuring the representation of all third sector organizations.}


Keywords: Public administration; third sector; governance; Gipuzkoan model; welfare mix; representation; interaction; relations; qualitative research.

Citation: Arrieta F., Izaguirre, A. \& Zuñiga, M. (2020). New Spaces in the Public Arena: Learnings from Gipuzkoa. Public Administration Issues, No 6 (Special Issue II) pp. 118-132 (in English), DOI: 10.17323/1999-5431-2020-0-6-118-132.

\section{The Third Sector in light of the reorganization of the Welfare mix}

The combination of different spheres for the provision of welfare is by no means a new phenomenon, as the "welfare mix" or the welfare and care schemes are in the origins of the welfare state (WS). However, WSs in Europe are currently searching for new ways to organize these schemes, and the interest in the subject is becoming increasingly relevant from the political and academic perspective. Following Brandsen and Pestoff (2006), this growing concern is primarily due to the difficulty of welfare states to respond to existing social needs, which is linked to the existence of ideological motivations.

At present, the main feature of this reorganization is that the state is gradually losing its central role while the other spheres are taking on more responsibilities. In this sense, we follow the scheme proposed by Pestoff (1998), which integrates the State, the market, the Third Sector and the Community as the main sources of welfare. Moreover, Henriksen, Smith and Zimmer (2015) argue that concepts such as hybridity, collaboration, co-production or co-creation, as well as "welfare mix" itself, are gaining more attention due to the withdrawal of the State from the provision of welfare. Given this loss of centrality of the state, the role of the rest of the spheres is said to be increasingly prominent, especially the third sector (Bode, 2006; Salamon, 2015). It is important to add that in every country these schemes are organized in very different ways, depending on the existing needs, the historical evolution and the ideological motivations. For example, regarding the third sector, while in some countries its involvement in welfare provision entails a new governance model (Kolin, 2009; Nałecz, Les \& Pielin'ski, 2015; Wathen \& Scott, 2014), for others, as occurs in Spain, it represents the status quo (Brandsen \& Pestoff, 2006; Brandsen \& Pape, 2015). This means that the participation of the third sector in the provision of services is nothing new for the great majority of European countries, but its role is increasingly prominent.

However, although this political-territorial fragmentation leads to different models, the review of the literature on this subject indicates that there are a series of global trends reshaping the third sector and its function in the welfare states throughout Europe. One of the trends observed in particular is the process of 'nonprofitization' of the welfare states, in which governments increasingly seek the collaboration of the third sector in the provision of services (Salamon, 2015).

On the other hand, this growing role of the third sector in welfare provision seems to go hand in hand with the 'marketization' of the sector (McKay et al., 2015). Marketization is a process whereby organizations professionalize their activity by adopting management practices and further adjusting to the bureaucratic requirements of public administrations. Several studies (Clifford, Rajme, 
\& Mohan, 2010; Dart, 2004; Guo, 2006; McKay et al., 2015; Salamon, 1993; Teasdale et al., 2013; Eikenberry, 2009; Ekinberry \& Kluver, 2004) analyze the process of marketization and the financing of third sector organizations. Originally, these organizations channeled the needs and demands of different social movements (Johansson et al., 2015), and while many have continued to be voluntary, community-based organizations, others have resulted in or have moved towards the provision of services and, therefore, have assumed a more commercial character. In other words, this process has led them to take on management and modes of operation which are more in line with the business world than with the associative one. One of the issues that exemplifies this trend is how the third sector's economic dependence on public administration has led it to become an 'extension' of the public sector and to adopt guidelines belonging to the bureaucratic culture of public administration, which has caused the contraction of its original purpose and function of channeling social demands and complaints (Izquieta, Callejo \& Prieto, 2008). Additionally, Wathen and Scott (2014) point out that government funding can entice non state actors to service delivery areas or activities that may not fit an organization's "original mission".

For Milbourne (2009), the growing emphasis on competitiveness and the demands of collaboration frameworks undermine trust and cooperative work between organizations and also affect the community. Although these mechanisms can have visible short-term results for institutions, they diminish the work of local communities, which increasingly position themselves as one of the main allies or spheres capable of dealing with current social problems. This trend, adds Milbourne (2009), can be useful to improve the efficiency of the money received by the organizations, especially in relation to the provision of services, but it penalizes small organizations, which are more linked to the local and community level and are confronted with the most acute problems. Other organizations which, although small, adapt to institutional demands, inevitably distance themselves from their users and the community environment. Eikenberry (2009) argues that it is necessary to create a narrative that counteracts the prevailing marketization trend, and that helps to build a more human, just and cooperative society and future. Whether we defend one narrative or the other, the marketization of the third sector is also clearly a global phenomenon (Maier, Meyer, \& Steinbereithner, 2016). In fact, the different narratives are considered two sides of the same coin, as they offer different answers to the challenges and dilemmas posed by the growing presence of the third sector in the provision of public services, and the growth of the organizations and the sector itself.

\section{Spaces for representation and types of relationships} between public administration and the third sector

The trends described above, and the role demanded and now adopted by the third sector determine not only its role in the provision of welfare within the welfare mix, but also its social function. This indicates that there is an asymmetric relationship between the third and the public sector, as a large number of organizations receive their funding primarily through agreements with public adminis- 
tration, on which they are economically dependent (McKay et al., 2015; Nałecz, Les \& Pielin'ski, 2015; Zimmer \& Pahl, 2018). Therefore, although third sector organizations can be formally seen as independent of the state, in practice there is a complex relationship of interdependence, which varies in intensity, meaning and impact (Macmillan, 2015). In short, although it is assumed that the state and the third sector are separate spheres, in reality governments play a very significant role in the associative world and that of voluntary and community action. And, consequently, it can be inferred that the third sector finds itself in a clearly disadvantageous position vis-à-vis the state (Macmillan, 2015). This happens mainly because they are dependent on public funding, making them more compliant to the needs or demands of public institutions.

This clearly has its effect on the relationship with public administrations and on the correlations of power that are established. It should be noted that when referring to the types of relationships, we do not refer only to the classic modes of collaboration, such as agreements and subsidies, but to the existence of spaces in which information and reflections are shared concerning the welfare model that we wish to build and which role each sphere should play. The relationship established in each context is the logical result of the existing mutual interdependence and an effective way of organizing a wide variety of services (Salamon \& Toepler, 2015), since the strengths of the third sector complement the shortcomings of governments in providing services, while governments complement the weaknesses of the sector through funding.

It can be affirmed that the role of the third sector in policy design is certainly limited compared to its role in implementation. However, there is an interest and a tendency to increase its participation (Nałecz, Les \& Pielin'ski, 2015; Pestoff, 2009), since responding effectively to current challenges requires a new form of governance in which third sector organizations not only participate in the execution of policies, but also in their design and development (Salamon \& Toepler, 2015). Although there is a growing trend for this participation, the debate revolves around how this participation can be made more effective.

In this regard, it has been pointed out that there are different collaboration 'styles' concerning relationships between different spheres (Oosterlynck et al., 2013) that have been classified, among others, by DiGaetano and Strom (2003), who identify five modes of governance (clientelist, corporatist, managerial, pluralist and popular), or by Najam (2000), who proposes the four C's to understand the different models of relationship between public administration and the third sector (cooperation, confrontation, complementarity, co-optation). However, apart from the decentralization practices, which are viewed as processes of 'devolution' to the more local levels of government and are seen as positive because they are more effective, participatory and sustainable (Oosterlynck et al., 2013), and apart from co-production with citizens (Pestoff, 2006, 2009, 2011, 2012) in the delivery of social services and provision of welfare (but not co-managing these services with the third sector), little attention has been paid to the specific instruments and spaces with which to carry out this governance or the coordination of the welfare mix, specifically between public institutions and the third sector. Particularly notable in this area is Ranci's contribution (2015) which reports on the evolu- 
tion of the relationship between public institutions and the third sector. The author suggests different ways of innovation and improvement such as the creation of a new legal framework, greater competition in financing mechanisms, and new forms of coordination, among which the 'tables of discussion' stand out. These should involve local or municipal governments, third sector organizations, trade unions and representatives of local employers jointly defining common objectives and criteria for the distribution of funding. These 'tables' are a clear example of an instrument for coordination between the public and the third sector, as well as for the third sector's participation in the design of public policies.

\section{Gipuzkoa as this study's setting}

Gipuzkoa is one of the three provinces in the Basque Country (Euskadi), representing approximately 33\% of the population in the region (720,595 inhabitants). Donostia/San Sebastián is the capital city, with 182,391 inhabitants (EUSTAT, 2020), which is $25 \%$ of the province's population. The rest of the population resides in urban conurbations, and therefore Gipuzkoa can be characterised as largely an urban and industrialised province. Furthermore, Gipuzkoa is known for the strength of its cooperative movement, also clearly visible in the social sector, where a strong and diverse range of third sector organisations play a central role in the welfare system of the province.

Within the third sector of Gipuzkoa, there is an underlying principle of subsidiarity which limits the sector's actions to those areas that public administration does not reach. This could be due to a long-established practice in the territory, which has gradually become part of the tradition of public policies (path dependence) through which they are understood in a shared, public-private, manner. This is what is commonly referred to as the 'Gipuzkoan model' of policy implementation (Ferran, 2017).

The public action framework of Gipuzkoa's local government's last legislature (2015-2019) was inspired by principles of public-private collaboration and the involvement of the third sector in managing public policies. These fundamental principles lie behind the "Etorkizuna Eraikiz - Building the Future" program, which founded the exercise of government powers over the past four years (Barandiaran, 2018) and will also determine, according to the newly elected responsible, the action program for the years ahead (2019-2023) (Olano, 2019). Behind this political - institutional momentum stands the current debate regarding the role of each of the actors involved.

Interaction instruments that currently exist, and therefore prompt the relation between the third sector and the public administration, can be distinguished as follows: the instruments for guaranteeing the provision of services, and the spaces for representation. The first kind of instruments refers to annual competitive subsidies or multiannual and more stable subsidies. In this sense, subsidies are important for the development of many initiatives and the implementation of social innovation programs, but they are precarious: rarely are they multi-year program plans, which makes it difficult to plan and implement these programs and the services that should be provided (Guiteras, 2012). 
Agreements, on the other hand, have been useful instruments that have provided greater stability to the relation between the public administration and the third sector in the provision of services. Reality nowadays is being subjected to debate between this figure's continuity and the transition towards economic agreements, thus establishing greater control from the public administration towards the third sector.

Beyond the interaction instruments that currently exist, the research questions to be answered are the following: Which type of relationship should be established between the public administration and the third sector in Gipuzkoa?; Which are the existing interaction flows between the public administration and the third sector in Gipuzkoa?; Are new interaction instruments between the public administration and the third sector necessary in Gipuzkoa?

We hypothesize that:

- Traditional ways of relationships between the public administration and the third sector in Gipuzkoa are insufficient, making it necessary to think of innovative ways of building these relationships.

- Although the creation of new interaction instruments such as the civil social dialogue table may give voice and representation to the third sectors' organizations, its implementation should be viewed in relation to its functions and characteristics.

\section{Method}

The research on which this article is based was drawn from a wider project named "Estrategia para impulsar el Tercer Sector Social en Gipuzkoa - Strategy to promote the Third Sector in Gipuzkoa", commissioned by Gipuzkoa's Provincial Council and Deusto University and aimed to design and define the regional strategy in order to implement Law No. 6/2016, of May 12th, of Gipuzkoa's Third Sector.

This qualitative study was developed following different stages: First, an informative session was conducted with coordinators of 71 different organizations of Gipuzkoa's third sector and also with public administration technicians. They received detailed information about the nature and purpose of the study and were encouraged to express their concerns and suggestions regarding the implementation of the study. Second, professionals from the public administration and the third sector were given the opportunity to participate in the semi-structured interviews designed by the research team. More specifically, nine participants agreed to take part in this qualitative process (four technicians and five organization managers). Those that declined to take part at this stage either reported being too busy to participate or had already taken part in similar research processes throughout the year. These qualitative questions referred to the nature of the existent relationship between the public administration and the third sector (e.g., How would you describe the existent relationship between the public administration and the third sector in Gipuzkoa? Are there any difficulties in this relationship? If so, which ones?) and the existing instruments and spaces for this relationship to happen (e.g., Which are the existing interaction flows between the public administration and the third sector in Gipuzkoa?). 
Interviews lasted 90 minutes approximately and were audio-recorded. The following table shows the participants main characteristics.

Table 1

\section{Characteristics of the participants taking part in the interviews}

\begin{tabular}{|c|c|c|c|}
\hline Code & Category & Job Title & Sex \\
\hline P1, P2, P3, P8 & Public administration & DFG Technicians & 3 Males \\
\hline P4, P5, P6, P7, P9 & Third sector & Organization manager & 2 Males \\
\hline
\end{tabular}

Sources: Everywhere, unless otherwise specified - research by authors.

In order to obtain a better overview of the transcribed interview material as a whole, the authors of the manuscript read through the entire interview material of the interviews several times to identify key categories. In line with the process of thematic content analysis, carried out with Atlas-ti 7.0 software, these key categories were the basis to code the entire interview material. Once researchers were satisfied with the thematic coding framework, each transcript was coded, and each instance of difficult or uncertain codings and possible new categories that emerged from the data were noted. These codings were discussed and jointly decided and new codes were either created or collapsed into existing categories. The third step of analysis was to identify patterns among these categories.

Having analyzed the interview material and in order to advance in the understanding of the information obtained, three focus groups were developed. While 11 professionals from the public administration took part in the first focus group (FG1), the second (FG2) and third (FG3) focus groups involved 11 and 12 professionals from Gipuzkoa's third sector. The following table shows the participants main characteristics:

Table 2

\section{Characteristics of the participants taking part in the focus groups}

\begin{tabular}{|c|c|c|c|c|}
\hline Code & Category & Job Title & $\begin{array}{c}\text { Number } \\
\text { of participants }\end{array}$ & Sex \\
\hline $\begin{array}{c}\text { Focus Group 1 } \\
\text { (FG1) }\end{array}$ & $\begin{array}{c}\text { Public } \\
\text { administration }\end{array}$ & $\begin{array}{c}\text { DFG } \\
\text { Technicians }\end{array}$ & 11 & 5 Males \\
\hline $\begin{array}{c}\text { Focus Group 2 } \\
\text { (FG2) }\end{array}$ & Third sector & $\begin{array}{c}\text { Organization } \\
\text { manager }\end{array}$ & 11 & 5 Males \\
\hline $\begin{array}{c}\text { Focus Group 3 } \\
\text { (FG3) }\end{array}$ & Third sector & $\begin{array}{c}\text { Organization } \\
\text { manager }\end{array}$ & 12 & 6 Females \\
\hline
\end{tabular}


The main topics discussed when developing these focus groups also referred to the themes commented on in the interviews, the nature of the existent relationship between the public administration and the third sector and the existing instruments and spaces for this relationship to happen. More specifically, and in order to clarify and complement the information obtained in the interview process, researchers mainly focused on the identification of existing instruments and spaces in order to guarantee collaboration and cooperation between both actors.

The three different focus groups were also audio-recorded with the permission of the participants and transcribed. As with the semi structured interviews, data obtained was subjected to thematic content analysis carried out with Atlasti 7.0 software. Key-themes were identified and divided into sub-topics.

To deepen and to provide a broader range of information, a contrast session was carried out with the professionals taking part in the three different focus groups.

\section{Analysis}

This paper qualitatively addresses the interaction between the public administration and the third sector in Gipuzkoa. Specifically, our research focuses on the existing instruments for this interaction and the existing spaces for representation and interaction between both. The main issue of debate regarding public interaction between the third and public sectors in the historical province of Gipuzkoa refers to the existing instruments and spaces for representation and interaction. But ultimately, the question is not only which type of relationships should be established, but also how the information flows are structured, what spaces make this possible, and who is represented in them; because, in the end, it is the organization and structuring of public power together with funding which are the most controversial issues amongst third sector organizations and within the public administration itself which is, by definition, reluctant to yield excessive power and transparency to other representative agents of the territory.

The analysis of the interview material led to the identification of the following topics: spaces for representation and interaction; and new spaces for representation and interaction. Below follows a description and also examples of excerpts from the analysed material. These excerpts are chosen to illustrate the different points of view that emerged from the data and represent the content of the material as a whole.

\section{Spaces for representation and interaction}

Concerning spaces for representation, we also identify different dynamics and logics, as in the previous point. In the first place, the people interviewed describe the third sector's 'own' spaces, which can be considered 'networks' or spaces generated as a result of the dynamics of networking in the third sector itself. These spaces have emerged as platforms based on demands and common work goals. In this sense, the following quote describes three main networks and associations characterized by Gipuzkoan third sector's presence. 
For example, in the province of Gipuzkoa there are networks and associations such as Sareginez ${ }^{1}$ and Sargi $i^{2}$, and also Gizalde ${ }^{3}$, since we also meet with third sector organizations that come to see us. P1, Public Administration.

Another space for representation is the one that has emerged between the third sector and public administration, about which serious doubts and questions are raised. Firstly, the public administration itself recognizes the meetings with technical staff, the agreement negotiations with the organizations or the calls for funding proposals as spaces for dialogue and representation. This idea is pictured in the narration of one of the participants:

Agreements are already, by definition, instruments of dialogue. In addition, there are the High Councils. And, if not, there is networking ... There is also another alternative, which we do not use too often, the financial support for social initiatives that can also be used to build relationships... P2, Public Administration.

In addition, both the third sector and public administration recognize the existence of representative councils of social areas in which many different organizations participate. In this sense, one of the participants describes having experienced feelings of weariness as third sector organizations are asked to take part in many different programs and initiatives thus questioning the efficiency of this participation.

I ask myself whether there are not any social councils in Gipuzkoa to channel these initiatives. I believe that, in the end, there are countless programs in which citizens are asked to participate, and we are represented in four or five places, always by the same people. I have the feeling that there are too many channels for participation, and I am not sure whether this is efficient in the end, because there are too many ways... FG2, Third Sector.

However, both sectors recognize that what is relevant is not so much the problem of the existence and structure of these spaces, but the opportunities they give people to really express their opinions and that these are taken into account, and consequently, the expectations that are generated around them. In fact, one of the main critiques observed when analyzing the transcribed material has to do with the lack of protagonism some of the third sector voices acquire. In this sense, professionals of the sector argue that although their presence is required in numerous meetings, the truth is that the relevant decisions are already taken even before asking them. These situations produce the feelings of boredom and weariness previously mentioned. This participant's narration reveals:

\footnotetext{
1 Network made up of non-profit volunteer organizations, which work in the historical province of Gipuzkoa and carry out programs of general and social interest.

2 Association for the Co-ordination of Social Organizations in Gipuzkoa.

3 Project launched by the Provincial Council of Gipuzkoa and Hezkide Eskola whose mission is to promote volunteering as a means of building an engaged and active civil society rooted in justice and solidarity.
} 
Social engagement is very popular nowadays but by the time you arrive at a given meeting everything has been decided ... I think we are fed up of attending forums and meetings which take time away from what really concerns us, of going to places where they have us reinventing the wheel... and I insist, everything holds up on paper. And there is already a sense of boredom, and then we have to go to another forum ... I think many of us are already very tired. FG3, Third Sector.

Another problem linked to spaces for representation has to do with people, or rather with the organizations that participate in these spaces. In the third sector itself, there is also a debate regarding the capacity of larger organizations, which have more resources, to influence and engage in dialogue in comparison to smaller organizations, whose capacity for dialogue is limited. As seen in the following quote, the third sector's main concern has to do with the participation of smaller organizations. Participants defend the importance of giving them [smaller organizations] voice and protagonism as they also respond to existing social needs.

What we cannot allow is that four organizations, and we all know which ones we are referring to, have all the share of the cake. The voices of smaller organizations should also be heard. FG3, Third Sector.

In an attempt to find a solution to this issue, the participant in the FG2 points out that the organization's size should not be viewed as a barrier to participate in the different spaces. Even if large organizations have much more stable communication channels than smaller ones, this participant highlights the need for smaller organizations to be able to count on more stable and direct information channels and representation.

We can look at possible ways for them to be effective and that, in some way, every organization is represented regardless of its size (...), which would be the right thing to do. FG2, Third Sector.

New spaces for representation and interaction: The Gipuzkoan civil dialogue table

Thus, the key question of the work process, the need to create a new space for dialogue between the public administration and the third sector in the territory as has been required by a higher law, has raised many doubts in society itself. In this sense, some of these doubts are closely related to the lack of knowledge regarding the work objective of this new space which, in turn, leads to a certain degree of uncertainty among third-sector professionals who doubt the productivity of this space.

It is a question of setting an objective. I have the impression that we talk a lot, but no specific objectives are put on the dialogue table and depending on the objective we can decide how to organize everything. FG1, Provincial Council Technician.

Regarding the civil dialogue table that is to be set up, I do not know to what extent it is going to be productive. FG1, Provincial Council Technician. 
Moreover, the existence of already established but not activated dialogue tables intensifies the feeling of uncertainty mentioned above, and therefore the need for new spaces for representation is again thrown into question. The following comment shows one participant's perspective:

Dialogue tables have already been set up but have not been opened. FG2, Third Sector.

This feeling of uncertainty is intensified if we take into consideration the discomfort that already exists among some third sector's professionals. Precisely, the following narration gathers a significant critique regarding the use given to existent spaces for representation. In this sense, this professional requires a better use of this new space, otherwise it will not be productive.

Now, if when we arrive, all the decisions have been made...and all we have to do is to agree with what the public administration wants to undertake according to its budget, that is another matter... FG3, Third Sector.

Clearly, we can distinguish different points of view among the third-sector professionals who support this initiative. Although participants express that this new space is not a brand-new initiative, it is seen as an opportunity and alternative for maintaining the communication channel with the public administration open. Here are the narrations of two of the participants:

If it is functional and executive, we are in favor of it. FG3, Third Sector.

I think it is positive that we can talk with the public administration, in this case through an organization. It is not exactly a new idea, but still... FG2, Third Sector.

Furthermore, one of the participants in the process opens the way for defining a possible aim for the functioning of this new space. In this sense, this person states that this new space should look for the participation of all the organizations in the third sector, regardless of their size, in order to identify their needs and channel them so that the public administration can provide them an answer.

If the purpose of this table is that associations get involved, that the needs of each association are identified, and if this table is an instrument for channeling those needs so that public administration can provide an answer, then I think that these tables should be supported. FG3, Third Sector.

In any case, there is a feeling that the existing interaction spaces, even those that could be created, do not respond efficiently to the elements of new governance, and that it is necessary to redesign both the spaces and the forms of interaction which make this possible by establishing trust relationships. But undoubtedly, it is regarding the instruments for interaction where more doubts about the future are raised. 


\section{Discussion}

While it is true that New Governance and New Public Management (NPM) is often spoken of, they mean, at least in part, construction and creation of new spaces in the public arena. In this sense, it is worth discussing how and to what extent these particular instruments are being or will be designed in the near future. Following Subirats and Rendueles (2016), we do not know if there is no light at the end of the tunnel, or if we will be 'run over' by the train coming from the other end of the tunnel.

As Eikenberry and Kluver (2014) suggest, when the Third Sector organizations are integrated into the scheme and institutional culture of the public sector, they have to adopt their regulations, laws and schemes to be recognized or legally authorized by them, and thus be able to receive support. This process can lead to the deterioration of the contribution made by Third Sector organizations in creating and sustaining a strong civil society. This is justified by, among other reasons, the fact that it can have a negative impact on the defense of their founding values and social rights, as well as on the generation of social capital.

Hence, there is much confusion in third sector organizations (but also in public administration itself) concerning the way in which to build these relationships. The traditional ways (agreements, subsidies) seem insufficient and the ways in which public administration builds relationships (councils or spaces for representation) make it difficult to represent a rich and complex third sector and, strangely enough, only seem to satisfy the largest organizations. One of the alternatives offered by public administration to develop relationships is the creation of civil dialogue groups in which all third sector organizations are represented, as proposed by Ranci (2015). However, and at the expense of its implementation, it seems that this tool has the same limitations that we previously described in the case analyzed.

In this sense, it is crucial to consider what the functions and characteristics of these groups or 'tables' should be. Firstly, the issue on which public administration and third sector organizations will work must be clarified, i.e., if it is a sector-specific issue, an issue that affects the entire third sector, or whether it has an impact on the whole welfare system, etc. Another aspect to be taken into account is the efficacy or effectiveness of these organizations, i.e., their capacity to make decisions on the issues addressed, beyond their mere advisory function. And finally, it is also relevant to know what types of representation instruments should be used, i.e., how to ensure that all third sector organizations, which make up a broad conglomerate, are represented. In this last respect, one of the main criticisms directed at the third sector is the legitimacy of its organizations and how they can be legally authorized in order to demand from these institutions a closer dialogue and greater engagement in policy design (Taylor \& Warburton, 2003).

On the other hand, the debate about these instruments shows that public authorities need to change their way of ruling and implementing policies. Nowadays, it is unclear if they are ready to do so. The path dependency of the institutions themselves and the resistance of the public servants to other ways of govern- 
ance are still big enough. Are there going to be politicians with strong leadership to make these changes happen? There are no clear signs in this direction.

What, therefore, does new governance imply? How can representation be achieved? Undoubtedly, the common spaces where public administration and the third sector interact, also through third parties (such as universities), can play a key role in this structuring and in generating innovative experiences.

\section{REFERENCES}

1. Barandiaran, X. (2018). La experiencia práctica de Etorkizuna Eraikiz - "Building the Future" practical experience. In Gipuzkoako Foru Aldundia. Experimentación Política Etorkizuna Eraikiz. Donostia: Alberdania - Provincial Council of Gipuzkoa. Political experimentation of "Building the Future". Donostia: Alberdania.

2. Bode, I. (2006). Disorganized Welfare Mixes: Voluntary Agencies and New Governance Regimes in Western Europe. Journal of European Social Policy, no 16, pp. 346-359. Available at: DOI: 10.1177/0958929706068273 (accessed: 10 December 2020).

3. Brandsen, T. \& Pape, U. (2015). The Netherlands: The Paradox of Government-Nonprofit Partners. Voluntas, no 26, pp. 2267-2282. Available at: DOI: 10.1007/s11266-015-9646-3 (accessed: 10 December 2020).

4. Brandsen, T. \& Pestoff, V. (2006). Co-Production, the Third Sector and the Delivery of Public Services. Public Management Review, vol. 8, no 4, pp. 493-501. Available at: DOI: 10.1080/14719030601022874 (accessed: 10 December 2020).

5. Clifford, D., Geyne Rajme, F. \& Mohan, J. (2010). How Dependent is the Third Sector on Public Sector Funding? Southampton: Third Sector Research Centre Working Paper 45.

6. Dart, R. (2004). Being "Business-Like" in a Nonprofit Organization: A Grounded and Inductive Typology. Nonprofit and Voluntary Sector Quarterly, vol. 33, no 2, pp. 290-310. Available at: DOI: 10.1177/0899764004263522 (accessed: 10 December 2020).

7. DiGaetano, A. \& Strom, E. (2003). Comparative Urban Governance: An Integrated Approach. Urban Affairs Review, no 38. Available at: DOI:10.1177/1078087402238806 (accessed: 10 December 2020).

8. Eikenberry, A.M. (2009). Refusing the Market. A Democratic Discourse for Voluntary and Nonprofit Organizations. Nonprofit and Voluntary Sector Quarterly, vol. 38, no 4, pp. 582-596. Available at: DOI: 10.1177/0899764009333686 (accessed: 10 December 2020).

9. Eikenberry, A.M. \& Kluver, J.D. (2004). The Marketization of the Nonprofit Sector: Civil Society at Risk? Public Administration Review, vol. 64, no 2, pp. 132-140.

10. EUSTAT (2020). Donostia-San Sebastián Available at: https://www.eustat.eus/municipal/ datos_estadisticos/donostia_san_sebastian_c.html (accessed: 10 December 2020).

11. Ferran, A. (2017). Loiolaetxea: Respuesta a la exclusión desde la solidaridad - Loiolaetxea: Solidarity response to exclusion. Zerbitzuan, no 64, pp. 213-226. Available at: DOI: 10.5569/11347147.64.15 (accessed: 10 December 2020). 
12. Guiteras, A. (2012). La relación entre público y privado en los Servicios Sociales: el papel del Tercer Sector - The relation between public and private in Social Services: The role of the Third Sector. Cuadernos de Trabajo Social, vol. 25, no 1, pp. 125-132.

13. Guo, B. (2006). Charity for Profit? Exploring Factors Associated with the Commercialization of Human Service Nonprofits. Nonprofit and Voluntary Sector Quarterly, vol. 35, no 1, pp. 123-138. Available at: DOI: 10.1177/0899764005282482 (accessed: 10 December 2020).

14. Henriksen, L.S., Smith, S.R. \& Zimmer, A. (2015). Welfare Mix and Hybridity. Flexible Adjustments to Changed Environments. Introduction to the Special Issue. Voluntas, no 26, p. 1591. Available at: DOI: 10.1007/s11266-015-9622-y (accessed: 10 December 2020).

15. Izquieta, J.L., Callejo, J.J. \& Prieto, J.M. (2008). El tercer sector y las administraciones públicas. Relaciones en el ámbito de la atención social en los niveles regional y local - The Third Sector and the Public Administrations. Relations in social attention field at regional and local levels. Revista Internacional de Sociología, vol. LXVI, no 49, pp. 115-138.

16. Johansson, H., Arvidson, M. \& Johansson, S. (2015). Welfare Mix as a Contested Terrain: Political Positions on Government - Non-Profit Relations at National and Local Levels in a Social Democratic Welfare State. Voluntas, no 26, pp. 1601-1619. Available at: DOI: 10.1007/s11266-015-9580-4 (accessed: 10 December 2020).

17. Kolin, M. (2009). The Role of the Third Sector in Changing the Welfare System: A Case Study of Serbia. Teorija in Praksa, vol. 46, no. 3, pp. 255-270.

18. Macmillan, R. (2015). Starting from Elsewhere: Reimagining the Third Sector, the State and the Market. People, Place and Policy, vol. 9, no 2, pp. 103-109. Available at: DOI: 10.3351/ ppp.0009.0002.0002 (accessed: 10 December 2020).

19. Maier, F., Meyer, M. \& Steinbereithner, M. (2016). Nonprofit Organizations Becoming Business-Like: A Systematic Review. Nonprofit and Voluntary Sector Quarterly, vol. 45, no 1, pp. 64-86. Available at: DOI: 10.1177/0899764014561796 (accessed: 10 December 2020).

20. McKay, S., Moro, D., Teasdale, S. \& Clifford, D. (2015). The Marketisation of Charities in England and Wales. Voluntas, no 26, pp. 336-354. Available at: DOI: 10. 1007/s11266-013-9417-y (accessed: 10 December 2020).

21. Milbourne, L. (2009). Remodelling the Third Sector: Advancing Collaboration or Competition in Community-Based Initiatives? Journal of Social Policy, vol. 38, no 2, pp. 277-297. Available at: DOI: Doi: 10.1017/S0047279408002845 (accessed: 10 December 2020).

22. Nałecz, S., Les, E. \& Pielinski, B. (2015). Poland: A New Model of Government-Nonprofit Relations for the East? Voluntas, no 26, pp. 2351-2378. Available at: DOI: 10.1007/s11266015-9653-4 (accessed: 10 December 2020).

23. Najam, A. (2000). The Four-C's of Third Sector - Government Relations. Cooperation, Confrontation, Complementarity, and Co-Optation. Nonprofit Management \& Leadership, vol. 10, no 4, pp. 375-396.

24. Olano, M. (2019). Diputatu nagusiaren izendapeneko hitzaldia, Batzar Nagusietako Osoko Bilkuran - Gipuzkoa's Provincial Councils Chairman's speech. Available at: www.gipuzkoa.eus/ eu/-/-elkarlanean-gipuzkoar-guztion-etorkizuna-bermatzeko-oinarri-sendoak-eraikikoditugu- (accessed: 10 December 2020).

25. Oosterlynck, S., Kazepov, Y., Novy, A., Cools, P., Wukovitsch, F., Sarius, T., ... Leubolt, B. (2013). Exploring the Multi-Level Governance of Welfare Provision and Social Innovation: Welfare Mix, Welfare Models and Rescaling. ImPRovE Discussion Papers, vol. 13, no 12, pp. 1-44. Available at: http://ideas.repec.org/p/hdl/improv/1312.html (accessed: 10 December 2020). 
26. Pestoff, V. (1998). Beyond the Market and State: Social Enterprises and Civil Democracy in a Welfare Society. Aldershot: Ashgate.

27. Pestoff, V. (2006). Citizens and Co-Production of Welfare Services. Childcare in Eight European Countries. Public Management Review, vol. 8, no 4, pp. 503-519. Available at: DOI:10.1080/14719030601022882 (accessed: 10 December 2020).

28. Pestoff, V. (2009). Towards a Paradigm of Democratic Participation: Citizen Participation and Co-Production of Personal Social Services in Sweden. Annals of Public and Cooperative Economics, vol. 80, no 2, pp. 197-224. Available at: DOI:10.1111/j.1467-8292.2009.00384.x (accessed: 10 December 2020).

29. Pestoff, V. (2011). Co-Produção, nova governança pública e serviços sociais no Terceiro Setor na Europa - Coproduction, new public gobernance and social services in Europe's Third Sector. Ciências Sociais Unisinos, vol. 47, no 1, pp. 15-24. Available at: DOI:10.4013/ csu.2011.47.1.02 (accessed: 10 December 2020).

30. Pestoff, V. (2012). Co-Production and Third Sector Social Services in Europe: Some Concepts and Evidence. Voluntas, vol. 23, no 4, pp. 1102-1118. Available at: DOI:10.1007/s11266-0129308-7 (accessed: 10 December 2020).

31. Ranci, C. (2015). The Long-Term Evolution of the Government - Third Sector Partnership in Italy: Old Wine in a New Bottle? Voluntas, no 26, pp. 2311-2329. Available at: DOI:10.1007/ s11266-015-9650-7 (accessed: 10 December 2020).

32. Razavi, S. (2007). The Political and Social Economy of Care in a Development Context Conceptual Issues, Research Questions and Policy Options. Ginebra: Gender and Development Programme Paper N 3. United Nations Research Institute for Social Development.

33. Salamon, L.M. (1993). The Marketization of Welfare: Changing Nonprofit and For-Profit Roles in the American Welfare State. Social Service Review, vol. 67, no 1, pp. 16-39.

34. Salamon, L.M. (2015). Introduction: The Nonprofitization of the Welfare State. Voluntas, no 26, pp. 2147-2154. Available at: DOI: 10.1007/s11266-015-9638-3 (accessed: 10 December 2020).

35. Salamon, L.M. \& Toepler, S. (2015). Government-Nonprofit Cooperation: Anomaly or Necessity? Voluntas, no 26, pp. 2155-2177. Available at: DOI: 10.1007/s11266-015-9651 (accessed: 10 December 2020).

36. Subirats, J. \& Rendueles, C. (2016). Los (bienes) comunes ¿oportunidad o espejismo? - The common (good) - opportunity or illusion?. Barcelona: Icaria.

37. Taylor, M. \& Warburton, D. (2003). Legitimacy and the Role of UK Third Sector Organizations in the Policy Process. Voluntas, vol. 13, no 3, pp. 321-338.

38. Teasdale, S., Kerlin, J., Young, D. \& Soh, J. (2013). Oil and Water Rarely Mix. Exploring the Relative Stability of Nonprofit Revenue Mixes Over Time. Third Sector Research Centre.

39. Wathen, M. \& Scott, A. (2014). Local Nonprofit Welfare Provision: The United States and Russia. Public Administration Issues, no 5, pp. 7-28.

40. Zimmer A. \& Pahl, B. (2018). Barriers to Third Sector Development. In: The Third Sector as a Renewable Resource for Europe. Palgrave Macmillan, Cham. Available at: DOI: 10.1007/978-3319-71473-8_5 (accessed: 10 December 2020). 